\title{
DNA repair is activated in early stages of p53-induced apoptosis
}

\author{
FJ Geske ${ }^{1}$, AC Nelson ${ }^{1}$, R Lieberman ${ }^{1}$, R Strange ${ }^{1,2}$, T Sun $^{1,3}$ \\ and LE Gerschenson*,1 \\ 1 Department of Pathology, University of Colorado Health Sciences Center, \\ Denver, Colorado, USA \\ 2 AMC Cancer Research Center, Lakewood, Colorado, USA \\ ${ }^{3}$ Veterans Affairs Medical Center, Denver, Colorado, USA \\ * Corresponding author: LE Gerschenson, University of Colorado Health \\ Sciences Center, Department of Pathology, Box B216, 4200 E. 9th Avenue, \\ Denver, C0 80262, USA. Tel: (303) 315-5329; Fax: (303) 315-6795; \\ E-mail: laz.gerschenson@uchsc.edu
}

Received 11.6.99; revised 13.12.99; accepted 17.1.00

Edited by $\mathrm{G}$ Ciliberto

\begin{abstract}
p53 is a complex molecule involved in apoptosis, cell cycle arrest, and DNA repair. Since apoptosis may play an important role in deletion of neoplastic cells, an understanding of the mechanism of p53-induced apoptosis may be critical for possible future therapeutic interventions. Recent evidence suggests that p53-induced apoptosis may involve members of the nucleotide excision repair (NER) family, linking these two cellular events. Our work using a temperature-sensitive p53 construct further analyzes p53-induced apoptosis in cultured murine mammary epithelial cells and also suggests that DNA repair plays a role in that process. Although p21 is induced in our system, apoptosis occurs without a detectable preceding G1 cell cycle arrest and independent of cellular alterations brought on by the temperature shift. In addition, clonogenic assays suggest that early stages of p53-induced apoptosis may be reversible upon removal of the apoptosis stimulus. As a possible explanation for this reversibility, our results show that general DNA repair activity increases early in $\mathrm{p} 53$-induced apoptosis. We also show that caspase-3 is activated at a timepoint when colony formation begins to drop, suggesting a possible mechanism for the point of no return in p53-induced apoptosis. Cell Death and Differentiation (2000) 7, 393-401.
\end{abstract}

Keywords: p53; apoptosis; DNA repair

Abbreviations: p53ts, temperature-sensitive p53; p53mut, constitutively mutant $\mathrm{p53}$; TUNEL, terminal deoxynucleotidyl-transferase mediated dUTP nick end labeling; NER, nucleotide excision repair

\section{Introduction}

Apoptotic cell death is a critical element in the defense against unrestrained cellular proliferation and its induction is the desired goal of many cancer therapies. ${ }^{1-3}$ Therefore, an understanding of the mechanisms regulating apoptosis is presently a major research focus. Among the many molecules implicated in its control, p53 is essential in apoptosis induced by DNA damage. ${ }^{4,5}$ Furthermore, p53's importance in tissue size homeostasis is reflected in the fact that it is mutated in over $50 \%$ of all human tumors. ${ }^{6,7}$ Accordingly, a complete understanding of the many facets of p53 function is crucial in advancing therapies and ultimately benefiting cancer patients.

The functional complexity of p53 is reflected in its roles in many cellular processes, such as apoptosis, G1 arrest, and DNA repair. p53 functions as a transcription factor and upregulates a number of genes involved in these processes. ${ }^{8}$ Perhaps the best understood function of p53 is its ability to induce $\mathrm{G} 1$ cell cycle arrest through the upregulation of $\mathrm{p} 21^{\text {Waf1/Cip } 1}$, which binds to and negatively regulates cyclin/cdk complexes. p21 is induced by p53 in times of cellular stress, transiently halting the cell cycle presumably to allow time for DNA repair to occur. ${ }^{9,10}$

Recently, attention has also focused on the role of p53 in DNA repair. ${ }^{11}$ One of p53's activities in repair involves its transcriptional activation of gadd45, which contains a p53binding site in its promoter.,12 GADD45 interacts with PCNA and stimulates nucleotide excision repair activity when overexpressed. ${ }^{13}$ p53 is also involved in repair through its direct interactions with critical components of the nucleotide excision repair machinery. Specifically, immunoprecipitation experiments have shown that p53 binds to three of the subunits of the TFIIH transcription/ repair complex: XPB, XPD, and the p62 subunit. ${ }^{14,15}$ p53's ability to recognize and bind to damaged DNA also suggests a role in repair, perhaps by localizing repair molecules to sites of damaged DNA through its ability to interact with both the DNA and proteins of the repair system. ${ }^{16,17}$

Unlike p53's direct action in eliciting G1 arrest through p21 upregulation, p53's mechanistic involvement in apoptosis is not completely understood. One pathway of apoptosis induction by $\mathrm{p} 53$ is through its transcriptional activation of bax ${ }^{18}$ a proapoptotic member of the bcl-2 family. ${ }^{3,19}$ However, this is not the only mechanism involved, as p53dependent apoptosis can proceed in a Bax-independent manner. ${ }^{20}$ In addition, p53 has been shown to upregulate a number of other genes that may be involved in apoptosis induction. For example, p53 transcriptionally activates PAG608, a nuclear zinc finger-containing protein that induced apoptosis when overexpressed. ${ }^{21} \mathrm{~A}$ similar study revealed that $\mathrm{p} 53$ activates a number of genes involved in the generation or response to oxidative stress, such as the human homologue of a mouse etoposide-inducible gene (Ei24) and certain oxidoreductases. ${ }^{22}$ Finally, p53 upregulates the TRAIL-receptor gene DR5/KILLER, which activates a caspase cascade upon ligand binding resulting in proteolysis of critical cellular proteins and cell death. ${ }^{23}$

Although much is known about p53-induced apoptosis, many questions remain to be answered. For example, how 
does p53 regulate and discriminate between a cell undergoing G1 arrest, DNA repair, and/or apoptosis? Can apoptosis occur in cells independent of cell cycle stage and p21 status? And finally, can apoptosis induction by p53 also involve induction of DNA repair pathways? Work in our laboratory is focused on the role of DNA repair in the process of apoptosis. Recent evidence suggests a direct involvement between members of the nucleotide excision repair family and p53 in the induction of apoptosis. In this study, the authors suggest that p53-induced apoptosis is attenuated in cells deficient in the repair enzymes XPB or XPD. ${ }^{24}$ Our current work further examines p53-induced apoptosis and also suggests a role for DNA repair. We show that p53-induced apoptosis can occur in spite of p21 upregulation but without a G1 cell cycle arrest. We also show that early stages of apoptosis may be reversible, and that DNA repair is activated early in the process. Finally, caspase studies suggest that activation of caspase-3 may signal the point of no return in these cells.

\section{Results}

\section{p53 induces apoptosis at the permissive temperature}

In order to study DNA repair in p53-induced apoptosis, we chose the MOD cell line, which is a mouse mammary carcinoma cell line ${ }^{25}$ that contains a truncated p53 mRNA and no detectable p53 protein. ${ }^{26}$ A temperature-sensitive $p 53$ plasmid was transfected into the MOD cells. This plasmid generates a $\mathrm{p} 53$ protein that is inactive at $37^{\circ} \mathrm{C}$, but by incubating these cells at the permissive temperature of $30^{\circ} \mathrm{C}$, the transfected p53 behaves as wildtype and is activated. ${ }^{27}$ Because p53 protein levels do not increase with time at $30^{\circ} \mathrm{C}$ (data not shown), p53 activation was examined through the ability to induce apoptosis and transcriptionally upregulate p21 in these cells. p53 temperature-sensitive cells (p53ts) were placed at $30^{\circ} \mathrm{C}$ for various times and the DNA was extracted and run on an agarose gel. The presence of oligonucleosomallength fragments of DNA by 12 and $18 \mathrm{~h}$ at $30^{\circ} \mathrm{C}$ is indicative of apoptosis (Figure 1) and shows that p53 is activated at the permissive temperature. In addition to the p53ts construct, we also made a constitutively mutant p53 cell line (p53mut) as a control for the p53ts cells. In this cell line, p53 is inactive at both $37^{\circ} \mathrm{C}$ and $30^{\circ} \mathrm{C}$. When DNA from p53mut cells treated at $30^{\circ} \mathrm{C}$ is run on an agarose gel, no fragmentation is seen, even by $18 \mathrm{~h}$ (Figure 1). This data shows that p53 is active in the p53ts cells at $30^{\circ} \mathrm{C}$ and induces apoptosis.

\section{Temperature-shift alone causes a reduction in DNA, RNA, and protein synthesis rates, but activation of p53 is necessary to induce apoptosis}

In order to determine the effects of temperature-shift on these cells, assays were done on both the p53ts and p53mut cells with ${ }^{3} \mathrm{H}$-thymidine, -uridine, and -amino acid incorporation at $37^{\circ} \mathrm{C}$ and for various times at $30^{\circ} \mathrm{C}$ (Figure $2 \mathrm{~A}, \mathrm{~B}$ ). These results show that temperature reduction in both cell lines results in similar decreases of DNA, RNA, and protein synthesis within $3 \mathrm{~h}$ at the permissive temperature. Note

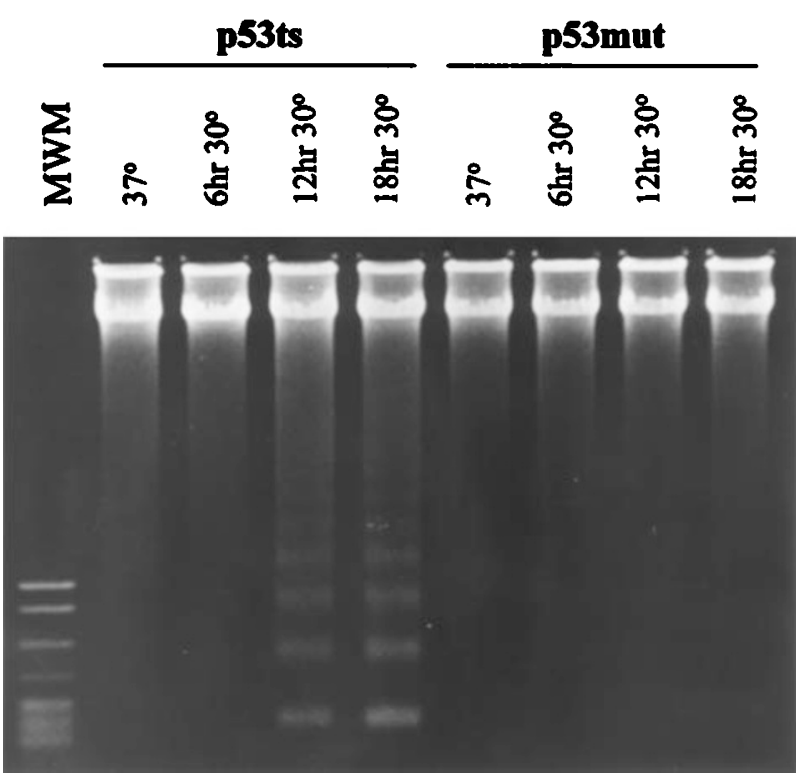

Figure 1 DNA is fragmented in p53 temperature-sensitive cells but not in p53 mutant cells with incubation at the permissive temperature. Cells were incubated at $37^{\circ} \mathrm{C}$ (control) or at $30^{\circ} \mathrm{C}$, and the DNA was extracted and run on a $1.5 \%$ agarose gel. Lane 1: molecular weight marker; lanes 2-5: p53ts DNA from $37^{\circ} \mathrm{C}$, and 6,12 , and $18 \mathrm{~h}$ at $30^{\circ} \mathrm{C}$, respectively; lanes 6-9: p53mut DNA from the same treatment groups

that these reductions are not due to active p53, as both the p53ts and p53mut cells are similarly affected. These results along with the DNA fragmentation analysis (Figure 1) confirm that it is active p53 that is inducing apoptosis in the p53ts cells at the permissive temperature and it is not just an effect of temperature shift.

\section{p53 induces p21, but G1 arrest does not occur}

p53 functions as a transcriptional activator of a number of genes, including p21, bax and gadd45.,8,28 In our cells, Bax and GADD45 proteins were found not to be upregulated the permissive temperature (data not shown). However, as an attempt to analyze p53 activation and cell cycle dependence on the induction of apoptosis and DNA repair, we examined p21 induction through immunoblotting. As seen in Figure $3 A$, p21 is induced within $6 \mathrm{~h}$ in the p53ts cells, and remains elevated throughout the timepoints studied. This is a p53dependent induction, as p21 levels in the p53mut cells are similar to that of the p53ts cells at the nonpermissive temperature of $37^{\circ} \mathrm{C}$ and do not change with time at the permissive temperature. Because p21 binds to and inactivates cyclin/cdk complexes and causes a G1 cell cycle arrest, ${ }^{10}$ we wanted to determine whether or not this p21 induction also caused a G1 cell cycle arrest in our system. To address this issue, cell cycle analysis was performed on logphase p53ts and p53mut cells. Cell were grown at $37^{\circ} \mathrm{C}$, and then shifted to $30^{\circ} \mathrm{C}$ for 6,12 , and $18 \mathrm{~h}$, and then the percentage of cells in each cycle phase was determined by flow cytometry. As Figure 3B illustrates, there is no $\mathrm{G} 1$ cell cycle arrest induced in these cells, even after $18 \mathrm{~h}$ at $30^{\circ} \mathrm{C}$. In addition, temperature shift to $30^{\circ} \mathrm{C}$ does not appear to affect 

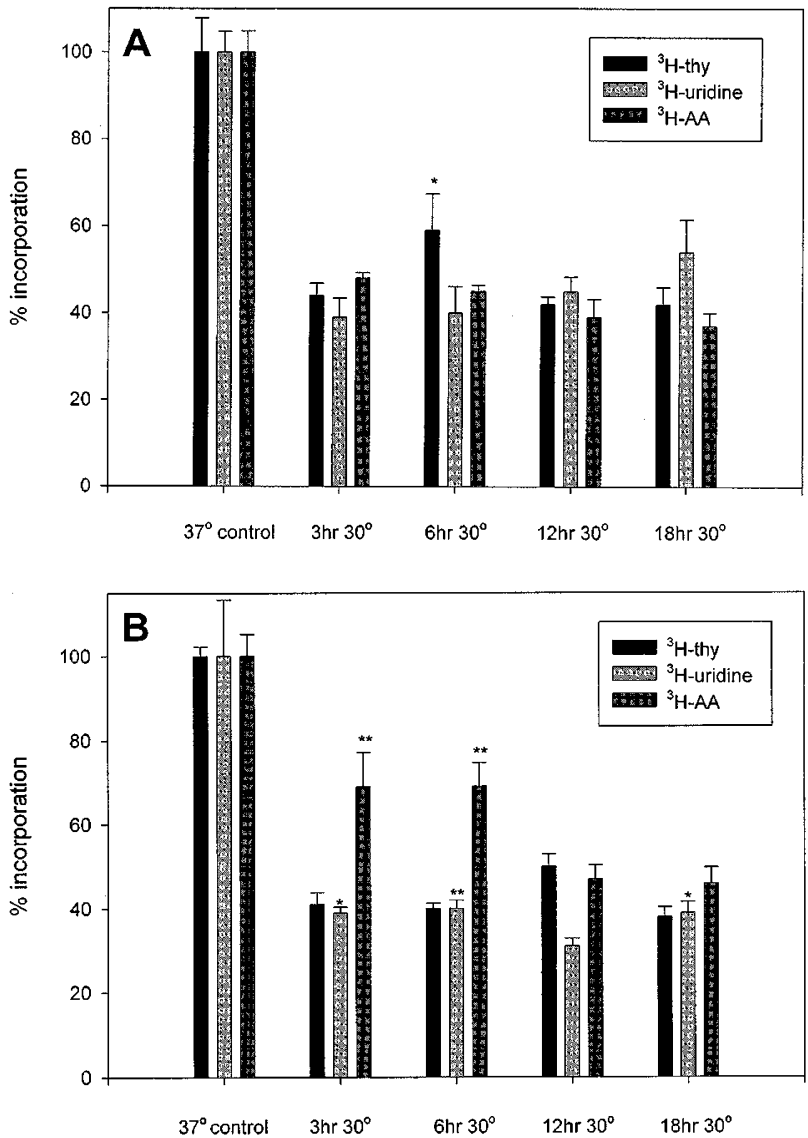

Figure 2 Temperature-shift reduces DNA, RNA, and protein synthesis independent of p53 activity. Cells were incubated at $37^{\circ} \mathrm{C}$ or $30^{\circ} \mathrm{C}$ for the indicated times. One $\mu \mathrm{Ci} / \mathrm{ml}$ of ${ }^{3} \mathrm{H}$-amino acids, ${ }^{3} \mathrm{H}$-uridine, or ${ }^{3} \mathrm{H}$-thymidine was added for the last hour of each treatment, and ${ }^{3} \mathrm{H}$-incorporation was measured by scintillation counting. Bars represent per cent incorporation ( \pm S.E.M.) compared to $37^{\circ} \mathrm{C}$ control cells, which were set at $100 \%$. (A) p53ts cells; all $P<0.001$ except ${ }^{*} P<0.007$. (B) p53mut cells; all $P \leqslant 0.001$ except ${ }^{*} P=0.002,{ }^{* *} P>0.004$. Statistical comparisons were between the $37^{\circ} \mathrm{C}$ and $30^{\circ} \mathrm{C}$ groups

the cell cycle, as both the p53ts and the p53mut cells are similarly unaffected (Figure 3B, C). These results suggest that p53 is indeed inducing p21 expression, but apoptosis is proceeding in a cell cycle-independent manner, and that apoptosis appears to occur without G1 arrest in these cells.

To support the contention that p53 activation and p21 upregulation do not result in cell cycle arrest in these cells, we determined the percentage of cells with labeled nuclei (labeling index, or L.I.) after a 1-h pulse with ${ }^{3} \mathrm{H}$-thymidine, followed by autoradiography. As seen in Table 1, both cell lines show a large percentage of cells with labeled nuclei at $37^{\circ} \mathrm{C}$, with similar small decreases at the permissive temperature. It is interesting that data obtained with L.I. does not fully correlate with the flow cytometry data. Quantitative comparison would be problematic since L.I. measures all attached cells, while flow cytometry measures only individual cells detached by trypsin treatment. Therefore, cell groups may fall outside the detection window. We also know that trypsin treatment damages some cells,
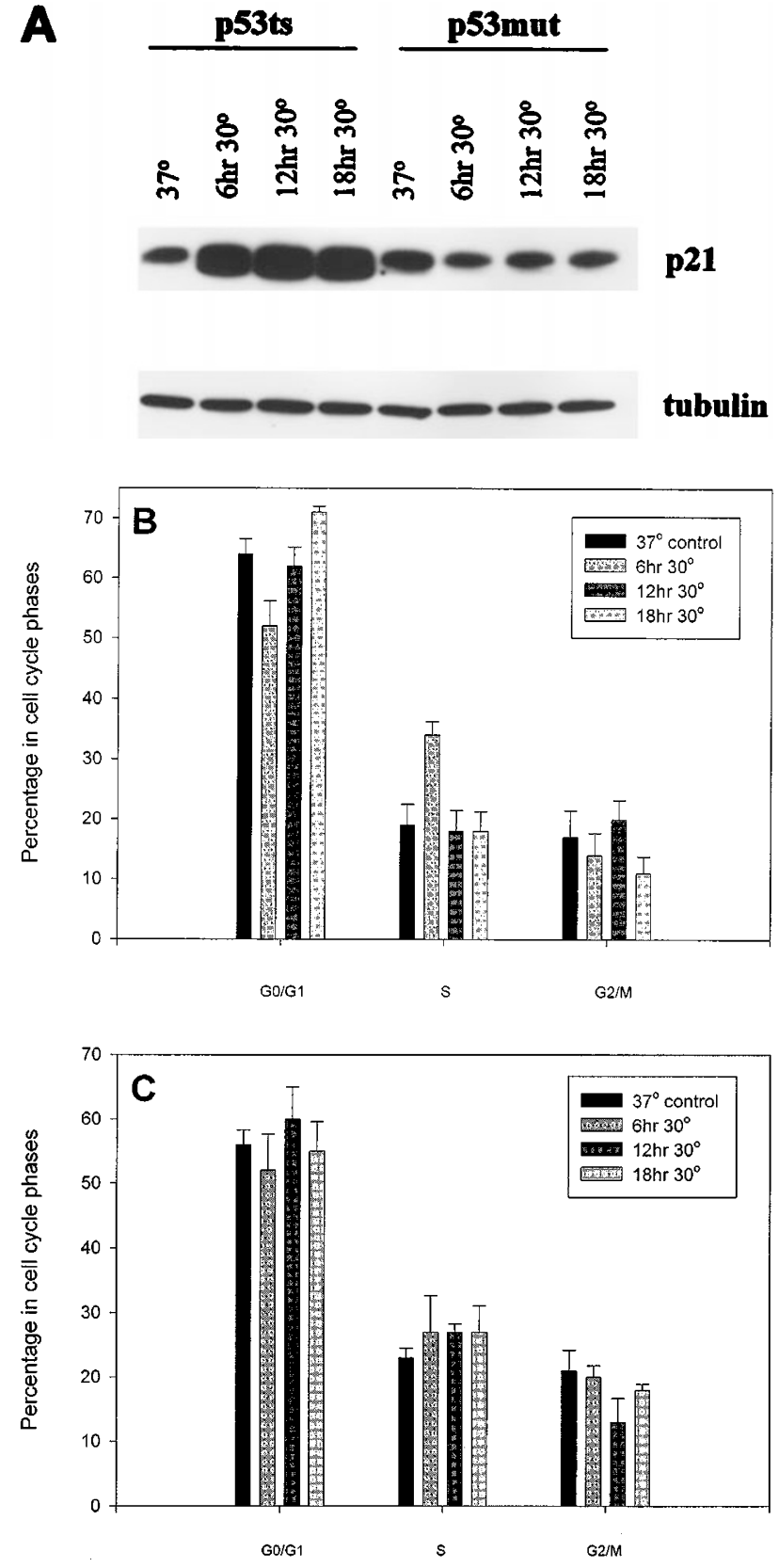

Figure 3 p53 upregulates p21 but does not induce $G$ arrest. (A) Protein extracts were obtained from p53ts and p53mut cells incubated at $37^{\circ} \mathrm{C}$ or $30^{\circ} \mathrm{C}$ for the indicated times, run on a $12 \%$ polyacrylamide gel, transferred to PVDF membranes and immunoblotted with anti-p21. The blot was then stripped and reprobed with anti- $\beta$-tubulin as a loading control. (B) Cell cycle analysis of p53ts cells. Cells were incubated at $37^{\circ} \mathrm{C}$ or $30^{\circ} \mathrm{C}$ for the indicated times, fixed, and analyzed by flow cytometry. Bars represent the percentage of cells from each treatment group in the different phases of the cell cycle ( \pm S.E.M.). (C) Cell cycle analysis for p53mut cells. For (B) and (C), differences within each group are not statistically significant

which would possibly result in further cell selection. However, this data provides further evidence for the lack of $\mathrm{G} 1$ arrest by p53 activation and suggests that the small decreases in L.I. are due to the lower temperature. 
Table 1 Labeling index in p53ts and p53mut cells

\begin{tabular}{lccrc}
\hline & \multicolumn{3}{c}{ L.I. } \\
\hline p53ts & A & $37^{\circ} \mathrm{C}$ & $59.0 \pm 1.7$ & $n=20$ \\
& $\mathrm{~B}$ & $6 \mathrm{~h} 30^{\circ} \mathrm{C}$ & $48.0 \pm 2.1$ & $n=20$ \\
p53mut & $\mathrm{C}$ & $37^{\circ} \mathrm{C}$ & $57 \pm 5.0$ & $n=15$ \\
& $\mathrm{D}$ & $6 \mathrm{~h} 30^{\circ} \mathrm{C}$ & $44.0 \pm 2.0$ & $n=20$ \\
\hline
\end{tabular}

p53ts and p53mut cells were incubated at $37^{\circ}$ or $30^{\circ} \mathrm{C}$ for $6 \mathrm{~h}$ in $35-\mathrm{mm}$ diameter culture dishes. For the last hour of incubation, $5 \mu \mathrm{Ci} / \mathrm{ml}{ }^{3} \mathrm{H}$-thymidine was added to the media. Cells were then fixed with methanol and dried, and Kodak NTB-2 emulsion was added to the dishes in the dark. After $24 \mathrm{~h}$, the emulsion was developed, and cells containing grains over the nucleus were counted. The labeling index (L.I.) is shown as the average percentage of positive cells, \pm S.E.M. ANOVA analysis: A vs $\mathrm{B}, P<0.001$; C vs $\mathrm{D}, P=0.01$

\section{Colony formation is not reduced during early stages of apoptosis}

In order to correlate actual cell survival with apoptosis induction, two methods were employed. First, we used the terminal deoxynucleotidyl-transferase mediated dUTP nick end labeling method (TUNEL) to determine the percentage of cells undergoing apoptotic DNA fragmentation induced by p53 activation (Figure 4A). Second, a clonogenic assay was used to determine cell viability (Figure 4B). As the TUNEL assay shows, apoptosis can be detected by $6 \mathrm{~h}$ after p53 activation, with approximately $15 \%$ of the cells staining positive. The percentages of apoptotic cells increase with increasing times at $30^{\circ} \mathrm{C}$, with $20 \%$ of the cells TUNELpositive by $12 \mathrm{~h}$, and $45 \%$ positive by $18 \mathrm{~h}$. Interestingly, the clonogenic assay reveals that after $6 \mathrm{~h}$ at $30^{\circ} \mathrm{C}$, colony formation remains at control levels, even though $15 \%$ of cells are apoptotic by the TUNEL assay at this time. At later stages of apoptosis, however, colony formation drops to approximately $60 \%$ after $12 \mathrm{~h}$ at $30^{\circ} \mathrm{C}$ and $25 \%$ after $18 \mathrm{~h}$. This suggests that early stages of apoptosis, but not later stages, may be reversible upon removal of the apoptotic stimulus.

\section{DNA repair is activated in early p53-induced apoptotic extracts}

For further characterization of early apoptotic cells, we decided to analyze one of the DNA repair pathways in apoptotic cells, nucleotide excision repair (NER). To accomplish this, we used a modified in vitro repair assay based upon a previously published method ${ }^{29}$ in which a plasmid (pUC19) was damaged with cisplatin and extracts from apoptotic cells were added to the damaged plasmid in the presence of labeled nucleotides. Cisplatin creates adducts in $\mathrm{DNA}^{30}$ that are repairable by NER, so if repair occurs in this assay, labeled nucleotides will be incorporated into the damaged plasmid. The process can then be measured by densitometry of the labeled pUC19. After incubating the cisplatin-treated pUC19 and an untreated control plasmid (pBR322) with ${ }^{32} \mathrm{P}$-dATP and extracts from p53ts and p53mut cells incubated at $37^{\circ} \mathrm{C}$ (controls) or $30^{\circ} \mathrm{C}$, the plasmids were repurified and run on an agarose gel (Figure 5A). The gel was then dried and exposed to film (Figure 5B). Densitometry of the pUC19 bands (Figure 5C) shows that NER in the non-apoptotic p53mut cells is reduced by temperature shift to $69 \%$ after $6 \mathrm{~h}$ at $30^{\circ} \mathrm{C}$ and almost
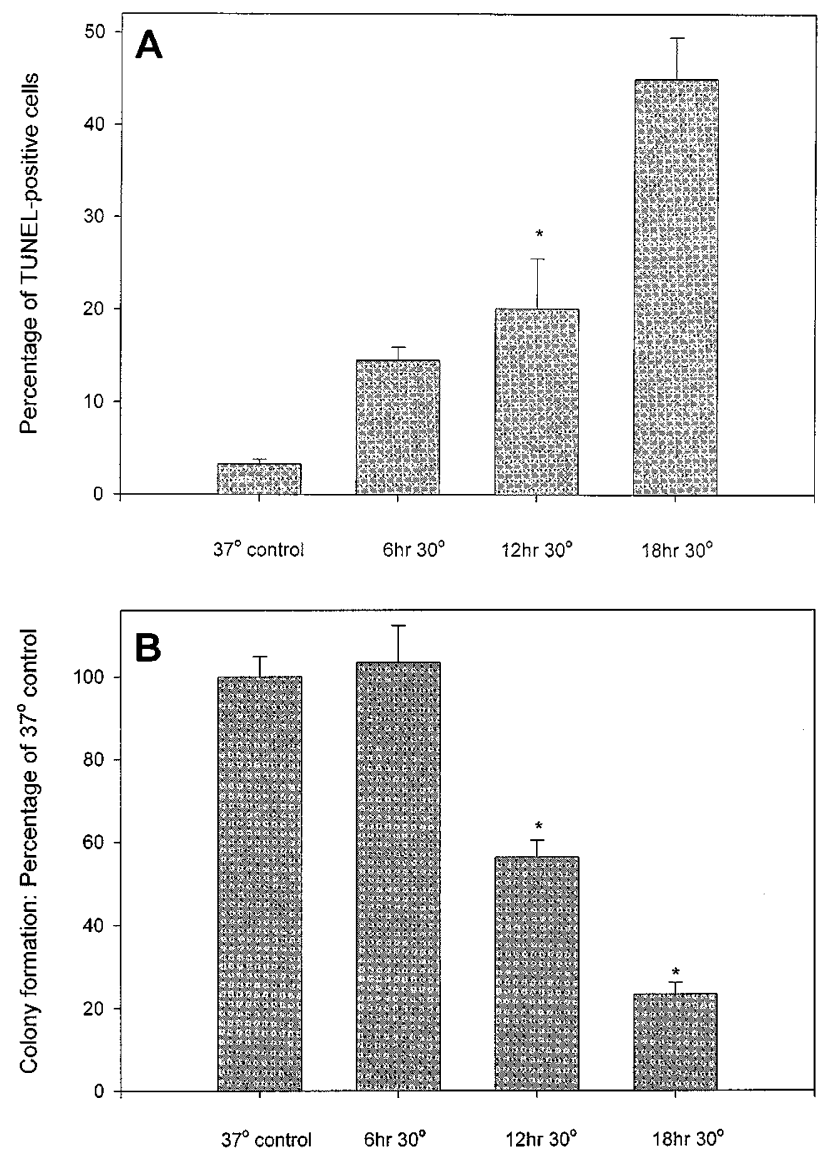

Figure 4 Colony formation is higher than expected in early stages of $p 53$ induced apoptosis. (A) TUNEL assay, p53ts cells. Cells were incubated at $37^{\circ} \mathrm{C}$ or $30^{\circ} \mathrm{C}$ for the indicated times and subjected to the TUNEL assay (Trevigen). Bars represent the percentage of TUNEL-positive cells counted in five different fields per treatment group $( \pm$ S.E.M.); all $P<0.001$ except ${ }^{*} P=0.006$. Statistical comparisons were between the $37^{\circ} \mathrm{C}$ and $30^{\circ} \mathrm{C}$ groups. (B) Clonogenic assays, p53ts cells. Cells were plated and left at $37^{\circ} \mathrm{C}$ for $24 \mathrm{~h}$, incubated at $37^{\circ} \mathrm{C}$ or $30^{\circ} \mathrm{C}$ for the indicated times, then returned to $37^{\circ} \mathrm{C}$ for the remainder of $72 \mathrm{~h}$. Cells were then fixed, and colonies were counted. The number of colonies counted from the $37^{\circ} \mathrm{C}$ control samples were set at $100 \%$, and the $30^{\circ} \mathrm{C}$ treatment groups were compared to the controls ( \pm S.E.M.); ${ }^{*} P<0.001$

completely inhibited by 12 and $18 \mathrm{~h}$ at $30^{\circ} \mathrm{C}$. In contrast, NER is not reduced in the apoptotic p53ts cells, but is actually activated in early stages, as both the 6-h and the 12-h timepoints at $30^{\circ} \mathrm{C}$ show even greater repair activity than the $37^{\circ} \mathrm{C}$ control extracts. This activity is not present in the latestaged apoptotic extract $\left(18 \mathrm{~h}\right.$ at $\left.30^{\circ} \mathrm{C}\right)$, as NER activity is greatly reduced. These results confirm that DNA repair is activated in early stages of p53-induced apoptosis.

\section{Caspase- 3 activity increases at $30^{\circ} \mathrm{C}$}

Because caspase activation appears to play a role in the demise of the apoptotic cell, ${ }^{31,32}$ we were interested in the timing of caspase activation in our p53-induced system. As p53 has been shown to activate caspase- $3,{ }^{33}$ we decided to analyze it in the p53ts cells. As seen in Figure 6, caspase- 3 is activated after $6 \mathrm{~h}$ at $30^{\circ} \mathrm{C}$, and its activity is maximal after 
p53ts

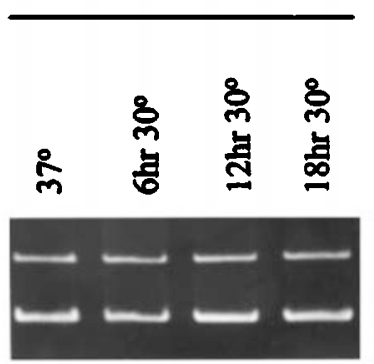

B
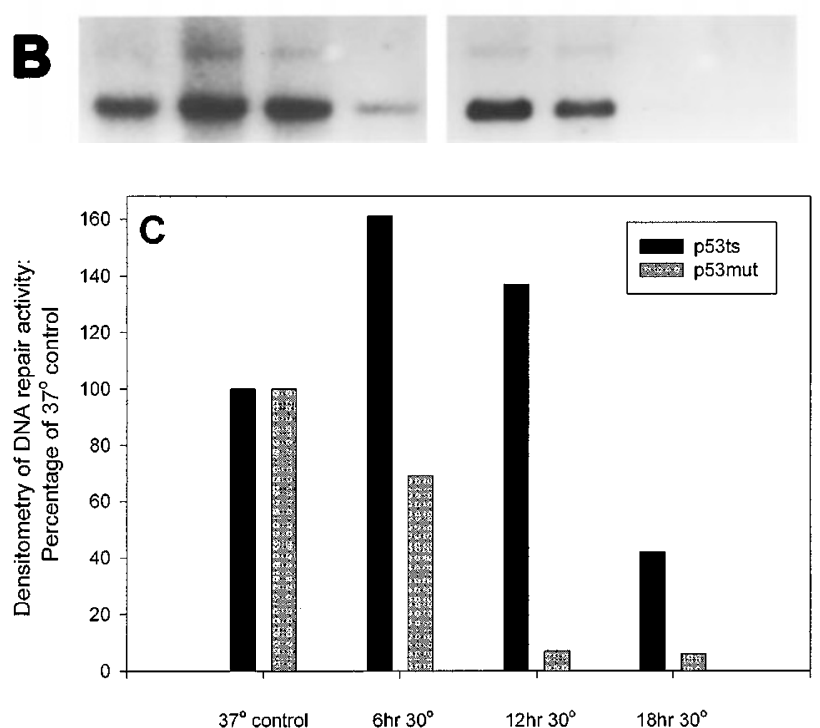

Figure 5 DNA repair is activated in early apoptotic extracts. An undamaged plasmid (pBR322, upper band) and a cisplatin-damaged plasmid (pUC19, lower band) were incubated in the presence of ${ }^{32} \mathrm{P}-\mathrm{dATP}$ with extracts from p53ts or p53mut cells incubated at $37^{\circ} \mathrm{C}$ or $30^{\circ} \mathrm{C}$ for 6,12 , or $18 \mathrm{~h}$. The plasmids were then purified and run on an agarose gel $(\mathbf{A})$. The gel was dried and exposed to X-ray film (B). Densitometry analysis was used to determine the amount of incorporation into the damaged plasmid, and bars in (C) represent the amount of incorporation from each extract into the cisplatindamaged pUC19 plasmid. The amount of repair seen in the $37^{\circ} \mathrm{C}$ controls was set at $100 \%$, and the $30{ }^{\circ} \mathrm{C}$ samples were compared to the controls. Similar results were seen on at least three separate experiments

$12 \mathrm{~h}$ at $30^{\circ} \mathrm{C}$. This $12-\mathrm{h}$ timepoint is concurrent with the drop in colony formation (see Figure 4B), suggesting a possible correlation between maximal caspase activation and the point of no return in p53-induced apoptosis.

\section{Discussion}

Although it is clear that 553 is actively involved in the induction of apoptosis, the actual mechanisms of this process remain uncertain. The present study attempts to further dissect the activities of p53 and determine the interrelations between $\mathrm{G} 1$ cell cycle arrest, DNA repair, and apoptosis. We show that early stages of p53-induced apoptosis may be reversible and that DNA repair is activated and may be involved in this reversibility.

Western blots and flow cytometry experiments show that p53-induced apoptosis can occur despite the induction of

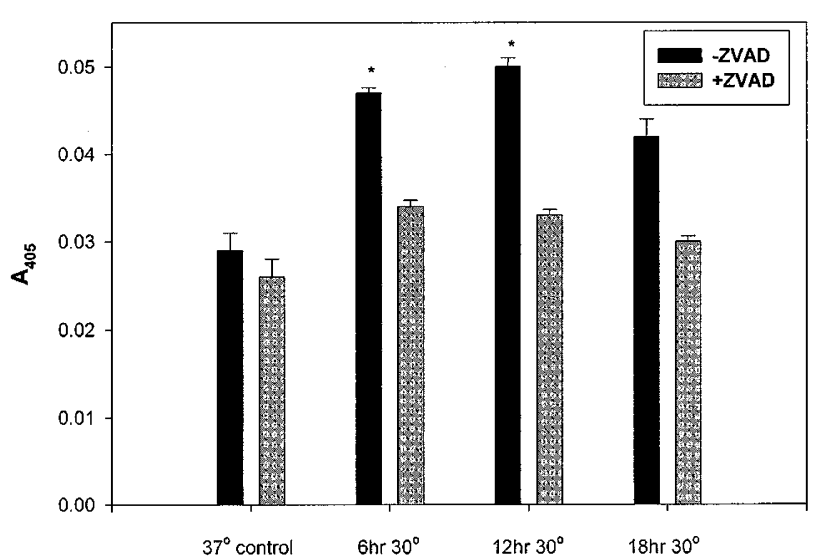

Figure 6 Caspase- 3 is maximally active at $12 \mathrm{~h}$ after p53 induction. Cells were treated at $37^{\circ} \mathrm{C}$ or $30^{\circ} \mathrm{C}$ for the indicated times, and cell extracts from each were measured for caspase-3 activity. The pan-caspase inhibitor z-VADfmk was added to the cells at the start of each incubation $(50 \mu \mathrm{M})$, and absorbance at $405 \mathrm{~nm}$ was measured for each sample ( \pm S.E.M.); ${ }^{\star} P=0.002$ compared to $37^{\circ} \mathrm{C}$ control. Bars show the average of three experiments

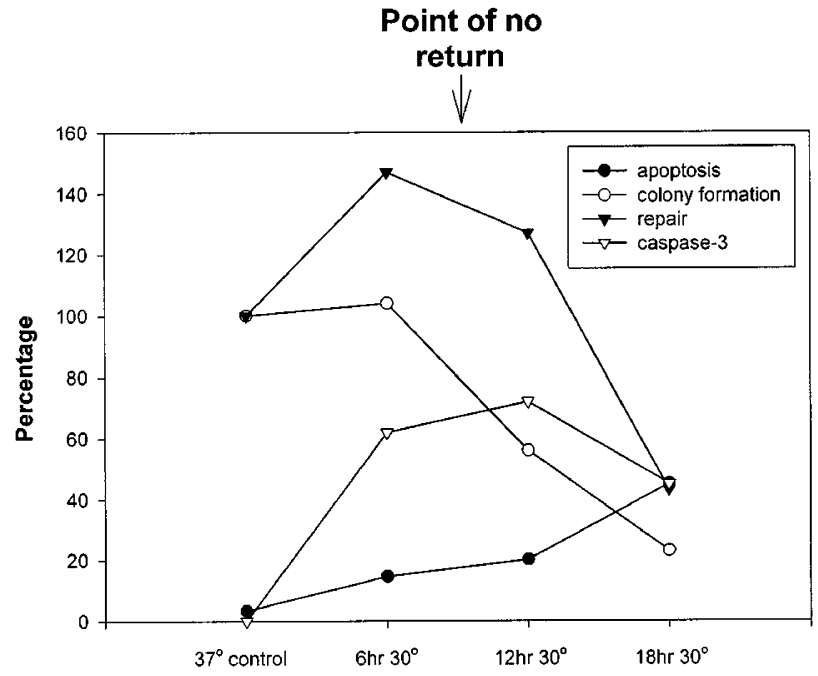

Figure 7 Results summary of p53ts cells. DNA repair is activated in early stages of p53-induced apoptosis, and colony formation remains at control levels. However, both repair and colony formation are reduced in late stages of the apoptotic process. Caspase- 3 levels are maximal at a time when colony formation levels begin to decline, suggesting a possible mechanism for the point of no return in these cells. Repair levels shown are the averages of four different in vitro repair assays. Apoptosis=percentage TUNEL-positive cells; colony formation=percentage of colonies formed at $30^{\circ} \mathrm{C}$ vs $37^{\circ} \mathrm{C}(100 \%)$; repair=percentage of repair activity at $30^{\circ} \mathrm{C}$ vs $37^{\circ} \mathrm{C}(100 \%)$; caspase$3=$ percentage increase of $30^{\circ} \mathrm{C}$ samples over $37^{\circ} \mathrm{C}$

p21 and independently of G1 cell cycle arrest (Figure 3 and Table 1). Previous studies have focused on the apoptosis versus cell cycle arrest properties of p53 and have shown that the induction of p21 is a common mechanism of p53induced G1 cell cycle arrest. ${ }^{9,10}$ Unlike other studies that have shown a dominant apoptotic response, ${ }^{34}$ we have shown that p53 can induce p21 upregulation and induce apoptosis simultaneously, without any preceding G1 arrest. Our data strongly suggests that either cell cycle arrest is 
not necessary for the induction of apoptosis, or that both phenomena may be unrelated in our experimental data.

Previous results in our laboratory have suggested that early stages of cycloheximide-induced apoptosis in human adrenocortical carcinoma cells may also be reversible, perhaps through DNA repair. ${ }^{35}$ Therefore, we have examined DNA repair in our p53-induced cell system. Since p53 is involved in DNA repair as well as apoptosis, ${ }^{11,36,37}$ we hypothesized that DNA repair may be active and play a regulatory role in p53-induced apoptosis. Consistent with this notion, our clonogenic assay results show that colony formation remains at control levels even at a time when $15 \%$ of the cells are TUNEL-positive (Figure 4). Although this experiment does not directly analyze DNA repair, it does reflect the possibility that early in the apoptotic process $\left(6 \mathrm{~h}\right.$ at $30^{\circ} \mathrm{C}$ in our system) cells can still survive if the apoptotic stimulus is removed. As TUNEL-positive cells contain fragmented DNA, this suggests DNA repair as a likely mediator in this reversibility.

There are many other cellular events occurring in various stages of apoptosis besides DNA fragmentation: caspase activation, ${ }^{38,39}$ mitochondrial signaling, ${ }^{40}$ and bcl-2 family interactions. ${ }^{3}$ We now have examined DNA damage and repair as molecular paradigms for cellular injury and repair. It is known that p53-mediated DNA repair activity is increased by UV irradiation, ${ }^{41-43}$ so we hypothesized that apoptotic DNA damage may have similar effects on DNA repair. In order to examine DNA repair capabilities in apoptotic cells, we chose an in vitro repair assay that analyzes nucleotide excision repair activity. Although we are not yet certain what pathway(s) would be used to repair apoptotic DNA, NER may be a good indicator of general DNA repair activity, as NER is the most common DNA repair pathway. ${ }^{44}$ Results of this assay show that the process of NER is actually upregulated in early stages of apoptosis (Figure 5). Interestingly, repair activity remains high even after $12 \mathrm{~h}$ of p53 induction, when colony formation levels begin to decline. Only after $18 \mathrm{~h}$ of p53 activation do we see a reduction in NER activity, when apoptosis levels are high and colony formation is significantly reduced. This is in direct contrast to NER activity in the non-apoptotic p53mut cells, which is reduced by temperature decrease. These results suggest that the process of p53-induced apoptosis itself may be activating DNA repair programs.

If early stages of p53-induced apoptosis are indeed reversible through DNA repair, it is of interest to determine when the point of no return occurs in this system. One possibility of an irreversible apoptotic event involves the destruction of cellular proteins through proteolysis by caspases. ${ }^{45}$ Recent studies have shown that caspase- 3 is necessary for DNA fragmentation and morphological changes in apoptosis. ${ }^{46}$ We therefore analyzed caspase-3 activation in our p53-induced apoptotic cells. As seen in Figure 6 , caspase- 3 is activated by $6 \mathrm{~h}$ after temperature shift, but gains maximal activity after $12 \mathrm{~h}$ of p53 activation. Interestingly, the 12-h timepoint is when colony formation begins to decline (Figure 4B), suggesting that maximal caspase-3 activity may indeed signal the point of irreversibility in p53-induced apoptosis. An alternative hypothesis suggests that, in chemically-induced forms of apoptosis involving p53, caspase activation occurs after the point of no return. ${ }^{47}$ In this model, caspases are responsible for later apoptotic phenotypes, but not for the actual commitment to cell death. This hypothesis would explain why in the p53ts cells colony formation is still at control levels after $6 \mathrm{~h}$ of p53 activation (Figure 4B), even though caspase-3 activity has already increased.

Figure 7 summarizes our results and shows the percentage of apoptotic cells, colony formation, and DNA repair and caspase-3 activities as a function of p53 induction. At early stages of p53-induced apoptosis, repair levels remain high, as does colony formation. With longer periods of p53 induction, however, colony formation drops and DNA repair levels are decreased. Because early stages of p53-induced apoptosis appear reversible and DNA repair activity remains functional, this suggests that the pathways involved in the apoptotic process do not result in early inhibition of DNA repair. However, certain repair molecules may eventually be cleaved and inactivated by caspases, ${ }^{48}$ and caspase- 3 is maximally activated by $12 \mathrm{~h}$ at the permissive temperature in our cells. As the point of no return occurs sometime between 6 and $12 \mathrm{~h}$ in these cells, caspase activation suggests a possible mechanism for irreversibility in apoptosis induction.

As previously mentioned, it is unclear what DNA repair pathways may be involved in repairing apoptotic DNA. Due to the nature of apoptotic DNA fragmentation, the doublestrand break repair pathway may be involved. The mechanisms of double-strand break repair remain unknown, but the DNA-dependent protein kinase (DNA-PK) is required. ${ }^{49,50}$ Interestingly, DNA-PK is a cleavage substrate for activated caspases. ${ }^{51}$ In addition, other DNA repair proteins are also cleaved by caspases, such as poly(ADP-ribose) polymerase. ${ }^{52}$ As previously discussed and as seen in Figure 6, maximal caspase activity occurs around $12 \mathrm{~h}$ after p53 activation in the temperaturesensitive cells, the same time that colony formation begins to decline. This suggests that molecules such as DNA-PK may be degraded and that the double-stranded DNA repair mechanisms will no longer function. However, as seen in the in vitro repair assay (Figure 5), NER is not inhibited, even by $12 \mathrm{~h}$ after p53 activation. It is possible that NER mechanisms are not subjected to inactivation by caspases and that repair still occurs even after the cell reaches an irreversible stage of apoptosis. This finding may reflect the evolutionary importance of maintaining the overall integrity of DNA repair mechanisms. ${ }^{53}$

The question then remains, what is the role of NER in apoptosis? Immunoprecipitation experiments have shown that 553 directly interacts with critical components of the NER machinery, namely XPB, XPD, and the p62 subunit. ${ }^{14,15,54}$ This suggests that p53 may be involved in recruiting these molecules to sites of damaged DNA, as p53 has been shown to recognize and bind to single-stranded or mismatched DNA. ${ }^{16,17}$ It is even of greater interest that cell lines containing mutations in XPB or XPD inhibited p53-induced apoptosis, ${ }^{24}$ suggesting a direct role for NER enzymes in the p53-induced apoptosis program. This implies that not only can repair reverse p53-induced apoptosis, but that repair molecules may be essential in the apoptotic process itself. 
An important issue is how broad the regulatory role of DNA repair is in apoptosis of other cell types. We mentioned above the possible role of NER components in p53-induced apoptosis. ${ }^{24}$ Our laboratory has also determined that xeroderma pigmentosum group $A$ cell lines that are deficient in DNA repair show an increase in UV-induced apoptosis when compared with normal fibroblasts (LE Gerschenson, et al, personal communication). The above results further suggest that DNA repair is involved in apoptosis regulation.

Our data fits two possible models. The first suggests that at the inducing temperature $\left(30^{\circ} \mathrm{C}\right), \mathrm{p} 53$ is activated, resulting in DNA damage, which is followed by increased DNA repair activity. Initial DNA damage is then repaired and apoptosis is reversed. However, some cells may reach a point of no return after which the DNA repair systems can no longer cope with the extensive damage and apoptotic cell death occurs. An alternative explanation would be that just decreasing the temperature to $30^{\circ} \mathrm{C}$ results in DNA damage. p53 recognizes that damage and signals for increased DNA repair activity, which could then trigger apoptotic cell death. We favor the former hypothesis, since cells containing the mutant p53 do not show evidence of DNA damage at the permissive temperature when compared with the p53ts cells (Figure 1). It still remains to be determined how p53 activation results in DNA damage and apoptotic cell death, which is an area of intense research.

Our work, along with others ${ }^{55}$ is beginning to suggest an order in apoptotic events. We hypothesize that early stages of apoptosis, including such early events as membrane phosphatidylserine flipping $^{56}$ and initial $50-300 \mathrm{~kb}$ DNA breaks, ${ }^{57}$ are reversible. Indeed, initial experiments with the p53ts cells using flow cytometry and fluorescent activated cell sorting show that early-staged PS-positive cells incubated at $30^{\circ} \mathrm{C}$ can survive if the apoptotic stimulus is removed and the cells are returned to $37^{\circ} \mathrm{C}$ (Geske et al, manuscript in preparation). This reversibility may be centered around DNA repair. If the apoptotic stimulus is removed and DNA repair remains active, cellular mechanisms such as transcription and translation can initiate again and rescue the cell. However, if DNA repair is overwhelmed by the amount of DNA damage (i.e. 200 bp fragments) and/ or if repair proteins are inactivated by caspase proteolysis, then the cell cannot recover and dies. We propose that it is the failure of repair that actually results in the irreversibility of p53-induced apoptosis. Further research will determine if this hypothesis applies to different cell types.

\section{Materials and Methods}

\section{Cell culture}

MOD cells were originally obtained from a mouse mammary carcinoma ${ }^{25}$ and contain a truncated p53 mRNA and nonfunctional p53 protein. ${ }^{26}$ We stably transfected these cells with either a temperature-sensitive p53 plasmid (p53ts) or a constitutively mutant p53 (p53mut). The p53ts plasmid results in a valine substituted for alanine at amino acid \#135 of the mouse protein, while the p53mut construct contains a cysteine to phenylalanine substitution at amino acid \#132. Both plasmids are a chimera of mouse p53 cDNA and genomic DNA under the transcriptional control of a Harvey sarcoma virus long terminal repeat. $^{27}$ Although the MOD parent cell line contains no p53, we felt the p53mut cell line was a better control for the p53ts cells in that there is only a single amino acid difference between the two cell lines. Both cell lines exhibit the same growth rate. These plasmids were cotransfected with a neo-resistance vector at a ratio of $20: 1$ (p53 vector : neoR vector) and cells are maintained in DMEM/F12 media supplemented with EGF $(12.5 \mathrm{ng} / \mathrm{ml})$, insulin $(10 \mu \mathrm{g} / \mathrm{ml}), 1 \%$ serum, and $200 \mu \mathrm{g} / \mathrm{ml}$ Geneticin (Gibco/BRL).

\section{DNA fragmentation analysis}

Cells were incubated at either $37^{\circ} \mathrm{C}$ or $30^{\circ} \mathrm{C}$ for indicated times. Media was then removed and digestion buffer was added $(0.1 \mathrm{M} \mathrm{NaCl}$, $10 \mathrm{mM}$ Tris $\mathrm{pH} 8,25 \mathrm{mM}$ EDTA, $0.5 \%$ SDS, $0.3 \mathrm{mg} / \mathrm{ml}$ proteinase $\mathrm{K}$ ). The cells were scraped off the plates with a rubber policeman and incubated at $50^{\circ} \mathrm{C}$ overnight, followed by a phenol/chloroform extraction and a chloroform extraction. DNA was then treated with RNase $(20 \mu \mathrm{g} / \mathrm{ml})$ for $1 \mathrm{~h}$ at $37^{\circ} \mathrm{C}$, followed by another phenol/ chloroform extraction, and purified by ethanol precipitation. The concentration of DNA was determined by $\mathrm{OD}_{260}$ measurement, and $30 \mu \mathrm{g}$ of DNA/lane was run on a $1.5 \%$ agarose gel (Trevigen) in a $0.25 \%$ Orange $G$ loading buffer, stained with ethidium bromide, visualized on a UV light box, and photographed. The molecular weight marker used was pBR322 cut by Hpall, which results in bands at 622 , 527,404 , and 309 base pairs, and a series of bands between 242 and 180 base pairs.

\section{TUNEL assay}

Cells were incubated at either $37^{\circ} \mathrm{C}$ or $30^{\circ} \mathrm{C}$ for indicated times. Cells were trypsinized $(0.05 \%$ trypsin, $0.02 \%$ EDTA), washed in HBSS (floating cells included), spun again and the pellet was fixed in $95 \%$ ethanol for $10 \mathrm{~min}$, followed by another spin. The cell pellet was then removed and placed on a piece of histology wrap paper, put into a cassette, and paraffin-embedded. Sections were then cut and put onto slides for TUNEL analysis. Slides were deparaffinized and treated with Cytopore (Trevigen) for $90 \mathrm{~min}$, followed by removal of excess endogenous peroxidase by a $5-$ min $\mathrm{H}_{2} \mathrm{O}_{2}$ treatment. The TUNEL assay was performed as per manufacturer's instructions (Trevigen), followed by staining with Red Counterstain B for 3 min. Positive cells stained blue and were counted on an Olympus BX40 microscope at $600 \times$. Two different investigators (FJ Geske and LE Gerschenson) viewed at least five separate fields per slide and the average number of positives were obtained.

\section{Western blotting}

Cells were incubated at either $37^{\circ} \mathrm{C}$ or $30^{\circ} \mathrm{C}$ for indicated times, the media removed, and RIPA buffer was added $(50 \mathrm{mM}$ Tris, $150 \mathrm{mM}$ $\mathrm{NaCl}, 2 \mathrm{mM}$ EDTA, $50 \mathrm{mM} \mathrm{NaF}, 1 \%$ Triton X-100, 1\% Nadeoxycholate, $0.1 \%$ SDS, $1 \mathrm{mM}$ DTT, $5 \mathrm{mM}$ Na-orthovanadate, $1 \mu \mathrm{g} / \mathrm{ml}$ aprotinin, $0.5 \mu \mathrm{g} / \mathrm{ml}$ leupeptin). Extracts were then scraped off the plates, boiled for $5 \mathrm{~min}$, and spun at 10000 r.p.m. for $30 \mathrm{~min}$. Twenty $\mu \mathrm{g} /$ lane (as determined by Bradford assay) was run on a $12 \%$ polyacrylamide gel in a loading buffer of $2 \%$ SDS, $10 \%$ glycerol, $60 \mathrm{mM}$ Tris $\mathrm{pH} 6.8$, and $2 \% \beta$-mercaptoethanol, transferred to PVDF membrane, blocked in 5\% blocking buffer (Amersham) $3-18 \mathrm{~h}$, and incubated with a p21 polyclonal antibody (Calbiochem) for $1 \mathrm{~h}$. Protein-antibody complexes are detected by the ECL/ECL-Plus method according to manufacturer's instructions (Amersham). Blots were stripped at $50^{\circ} \mathrm{C}(100 \mathrm{mM} \beta$-mercaptoethanol, $2 \% \mathrm{SDS}, 62.5 \mathrm{mM}$ Tris- $\mathrm{HCl} \mathrm{pH} \mathrm{6.7)} \mathrm{for} 30 \mathrm{~min}$, blocked overnight, and reprobed with a 
mouse monoclonal anti- $\beta$ tubulin antibody (Boehringer Mannheim) as a loading control.

\section{Flow cytometry}

Cells were incubated at either $37^{\circ} \mathrm{C}$ or $30^{\circ} \mathrm{C}$ for indicated times, trypsinized and washed twice in PBS, and then resuspended in cold $70 \%$ ethanol. Cells were again washed in PBS, resuspended at a concentration of $2.5 \times 10^{6} \mathrm{cells} / \mathrm{ml}$ in $200 \mu \mathrm{l}$, and then treated with $100 \mu \mathrm{g}$ propidium iodide and 400 units RNase for $30 \mathrm{~min}$ at $4^{\circ} \mathrm{C}$. Cellular DNA content was then analyzed using a Coulter XL flow cytometer, and cell cycle analysis was carried out using Phoenix software.

\section{Labeling index}

Cells were incubated at either $37^{\circ} \mathrm{C}$ or $30^{\circ} \mathrm{C}$ for $6 \mathrm{~h}$ in $35 \mathrm{~mm}$ diameter culture dishes. ${ }^{3} \mathrm{H}$-thy $(5 \mu \mathrm{Ci} / \mathrm{ml})$ was added to the media for the last hour of incubation, and cells were then fixed with $100 \%$ methanol and air-dried overnight. Kodak NTB-2 emulsion was then added to each dish, which were stored in the dark for 4 days. The emulsion was then developed, and cells containing at least 5 grains over the nucleus were counted as positive, since less than 5 grains per nuclei was established as background.

\section{${ }^{3} \mathrm{H}$-incorporation assays}

Cells were incubated at either $37^{\circ} \mathrm{C}$ or $30^{\circ} \mathrm{C}$ for indicated times. One $\mu \mathrm{Ci} / \mathrm{ml}$ of ${ }^{3} \mathrm{H}$-amino acids, ${ }^{3} \mathrm{H}$-uridine, or ${ }^{3} \mathrm{H}$-thymidine was added for the last $1 \mathrm{~h}$ of each treatment. Dishes were then rinsed five times in PBS, followed by addition of either $20 \%$ TCA or $0.5 \mathrm{M} \mathrm{NaOH}$. Proteins, RNA, or DNA were then vacuumed through $0.45 \mu$ filters (Millipore) and counted by scintillation counters. Each treatment group also had total DNA content measured by Hoescht assay to account for cell number, and results are analyzed as c.p.m/ $\mu$ g DNA.

\section{Clonogenic assays}

Two thousand cells were plated on $35 \mathrm{~mm}$ diameter culture dishes and allowed to attach overnight at $37^{\circ} \mathrm{C}$. Dishes were either left at $37^{\circ} \mathrm{C}$ for $72 \mathrm{~h}$ (control) or put at $30^{\circ} \mathrm{C}$ for 6,12 , or $18 \mathrm{~h}$, then returned to $37^{\circ} \mathrm{C}$ for the remainder of $72 \mathrm{~h}$. Cells were fixed for $2 \mathrm{~min}$ in methanol, dried, and stained with $0.1 \%$ toluidine blue. Colonies counted as positive contained eight or more cells (representing at least three cell doublings). The number of colonies obtained in the $72-\mathrm{h} 37^{\circ} \mathrm{C}$ dishes was set at $100 \%$ and compared to the $30^{\circ} \mathrm{C}$-treated dishes. To control for groups of cells that may have attached upon initial plating, dishes were examined just $18 \mathrm{~h}$ after plating. The number of cell groups containing eight or more cells counted was consistently between 5 and $10 \%$ of the number of colonies counted in the $37^{\circ} \mathrm{C}$ control treatments. Therefore, this background was found not to influence the final colony counts or statistical analysis. In addition, this assay was also performed by treating cells at $37^{\circ} \mathrm{C}$ or $30^{\circ} \mathrm{C}$ first, and then replating the cells and counting colonies after $72 \mathrm{~h}$. Both techniques showed similar results but the former was chosen for its simplicity.

\section{In vitro repair assay}

The in vitro repair assay is based on a similar assay described by Wood et al. ${ }^{29}$ Cell extracts were first prepared from cells incubated at either $37^{\circ} \mathrm{C}$ or $30^{\circ} \mathrm{C}$ for 6,12 , and $18 \mathrm{~h}$. After incubation, cells were harvested, washed in PBS and homogenized. Proteins were precipitated with ammonium sulfate and concentrated by two spins in Amicon 3 microconcentrator tubes. Bradford assays were used to determine final protein concentration. The repair assay was then conducted and occurs in a buffer of HEPES $(45 \mathrm{mM}), \mathrm{KCl}(70 \mathrm{mM})$, $\mathrm{MgCl}_{2}$ (7.4 mM), EDTA (0.4 mM), ATP (2 mM), $20 \mu \mathrm{M}$ of dGTP, dCTP, and dTTP, phosphocreatine $(40 \mathrm{mM})$ and creatine phosphokinase $(2.5 \mu \mathrm{g})$ along with $300 \mathrm{ng}$ each of pBR322 (undamaged) and pUC19 (damaged with $0.01 \mu \mathrm{M}$ cisplatin, $16 \mathrm{~h}$ at $37^{\circ} \mathrm{C}$ ). To the repair reaction, $4 \mu \mathrm{Ci}$ of ${ }^{32} \mathrm{P}-\mathrm{dATP}$ and $40 \mu \mathrm{g}$ of cell extract were added, and the reaction was incubated at $30^{\circ} \mathrm{C}$ for $6 \mathrm{~h}$. The reaction was terminated with EDTA and plasmids were extracted by ProCipitate (CPG, Inc.) and precipitated with ethanol. Plasmids were then resuspended and linearized with $E c o R I$ and run on a $1 \%$ agarose gel. The gel was dried and exposed to Kodak XAR film. Densitometry analysis (STORM system, Molecular Dynamics) determined the amount of incorporation into the damaged pUC19 plasmid and was used as a measure of NER. The amount of incorporation in the control cells $\left(37^{\circ} \mathrm{C}\right)$ was set at $100 \%$ and compared to the experimental conditions $\left(30^{\circ} \mathrm{C}\right)$.

\section{Caspase-3 assay}

Cells were incubated at either $37^{\circ} \mathrm{C}$ or $30^{\circ} \mathrm{C}$ for the indicated times, washed in HBSS, trypsinized, and pelleted by centrifugation. The pancaspase inhibitor Z-VAD-fmk was added to the appropriate cells at the start of each incubation $(50 \mu \mathrm{M})$. Cells were then washed once in cold PBS and spun again. Final cell pellets were resuspended in $150 \mu \mathrm{l}$ of cell lysis buffer (Promega) and snap-frozen in a methanol/dry ice bath. The cells were then quick-frozen and thawed two more times, followed by incubation on ice for $15 \mathrm{~min}$. The cell suspensions were then spun at 10000 r.p.m. for $30 \mathrm{~min}$ and supernatants were collected. The Bradford assay was used to determine protein concentration of each sample (in triplicate). Caspase-3 activity was then measured using the CaspACE assay system (Promega) according to manufacturer's instructions, and absorbance at $405 \mathrm{~nm}$ was measured by a 96-well plate reader (Molecular Devices, Inc).

\section{Statistical analysis}

All statistics were performed by analysis of variance (ANOVA) using the Stats Plus program (Human Systems Dynamics).

\section{Acknowledgements}

We thank Dr. Moshe Oren for the p53 plasmids. This work was supported by the National Institutes of Health and the R Herbert and Alma Manweiler Research Endowment, University of Colorado Health Sciences Center.

\section{References}

1. Soini Y, Paakko P and Lehto V-P (1998) Histopathological evaluation of apoptosis in cancer. Am. J. Pathol. 153: 1041-1053

2. Barnes DM and Camplejohn RS (1996) p53, apoptosis, and breast cancer. J. Mamm. Gland. Biol. Neopl. 1: 163-175

3. White $E$ (1996) Life, death, and the pursuit of apoptosis. Genes Dev. 10: 1-15

4. Hansen R and Oren M (1997) p53; from inductive signal to cellular effect. Curr. Opin. Gene. Dev. 7: 46-51

5. Chen X, Ko LJ, Jayaraman L and Prives C (1996) p53 levels, functional domains, and DNA damage determine the extent of the apoptotic response of tumor cells. Genes Dev. 10: 2438-2451

6. Hollstein M, Sidransky D, Vogelstein B and Harris CC (1991) p53 mutations in human cancers. Science 253: 49-53 
7. Greenblatt MS, Bennett WP, Hollstein M and Harris CC (1994) Mutations in the p53 tumor suppressor gene: clues to cancer etiology and molecular pathogenesis. Cancer Res. 54: 4855-4878

8. Ko LJ and Prives C (1996) p53: puzzle and paradigm. Genes Dev. 10: $1054-$ 1072

9. El-Deiry WS, Tokino T, Velculescu VE, Levy DB, Parsons R, Trent JM, Lin D, Mercer WE, Kinzler KW and Vogelstein B (1993) WAF1, a potential mediator of p53 tumor suppression. Cell 75: 817-825

10. Harper JW, Adami GR, Wei N, Keyomarsi Kand Elledge SJ (1993) The p21 cdkinteracting protein $\mathrm{Cip} 1$ is a potent inhibitor of $\mathrm{G} 1$ cyclin-dependent kinases. Cell 75: $805-816$

11. Smith ML and Fornace Jr AJ (1996) The two faces of tumor suppressor p53. Am. J. Pathol. 148: 1019-1022

12. Sanchez $Y$ and Elledge SJ (1995) Stopped for repairs. BioEssays 17: $545-548$

13. Smith ML, Chen I-T, Zhan Q, Bae I, Chen C-Y, Gilmer TM, Kastan MB, O'Connor PM and Fornace Jr AJ (1994) Interaction of the p53-regulated protein Gadd45 with Proliferating Cell Nuclear Antigen. Science 266: 1376-1380

14. Wang XW, Forrester K, Yeh H, Feitelson MA, Gu J-R and Harris CC (1994) Hepatitis $B$ virus $X$ protein inhibits p53 sequence-specific DNA binding, transcriptional activity, and association with transcription factor ERCC3. Proc. Natl. Acad. Sci. USA 91: 2230-2234

15. Wang XW, Yeh H, Schaeffer L, Roy R, Moncollin V, Egly J-M, Wang Z, Friedberg EC, Evans MK, Taffe BG, Bohr VA, Weeda G, Hoeijmakers JHJ, Forrester K and Harris CC (1995) p53 modulation of TFIIH-associated nucleotide excision repair activity. Nat. Genet. 10: 188-195

16. Jayaraman $L$ and Prives $C$ (1995) Activation of $p 53$ sequence-specific DNA binding by short single strands of DNA requires the p53 C-terminus. Cell 81: $1021-1029$

17. Lee S, Elenbass B, Levine A and Griffith J (1995) p53 and its $14 \mathrm{kDa}$ C-terminal domain recognize primary DNA damage in the form of insertion/deletion mismatches. Cell 81: 1013-1020

18. Miyashita T, Krajewski S, Krajewska M, Wang HG, Lin HK, Liebermann DA Hoffman B and Reed JC (1994) Tumor suppressor $p 53$ is a regulator of $b c l-2$ and bax gene expression in vitro and in vivo. Oncogene 9: 1799-1805

19. Adams JM and Cory S (1998) The Bcl-2 protein family: arbiters of cell survival. Science 281: $1322-1326$

20. Canman CE, Gilmer TM, Coutts SB and Kastan MB (1995) Growth factor modulation of p53-mediated growth arrest versus apoptosis. Genes Dev. 9: $600-611$

21. IsraeliD, TesslerE, HauptY, Elkeles A, Wilder S, Amson R, Telerman A and Oren M (1997) A novel p53-inducible gene, PAG608, encodes a nuclear zinc finger protein whose overexpression promotes apoptosis. EMBO J. 16: 4384-4392

22. Polyak K, Xia Y, Zweier JL, Kinzler KW and Vogelstein B (1997) A model for p53induced apoptosis. Nature $389300-305$

23. Wu GS, Burns TF, McDonald ERI, Jiang W, Meng R, Krantz ID, Kao G, Gan D-D, Zhou J-Y, Muschel R, Hamilton SR, Spinner NB, Markowitz S, Wu G and EI-Deiry WS (1997) KILLER/DR5 is a DNA damage-inducible p53-regulated death receptor gene. Nat. Genet. 17: 141-143

24. Wang XW, Vermeulen W, Coursen JD, Gibson M, Lupold SE, Forrester K, Xu G Elmore L, Yeh H, Hoeijmakers JHJ and Harris CC (1996) The XPB and XPD DNA helicases are components of the p53-mediated apoptosis pathway. Genes Dev. 10: $1219-1232$

25. Medina D, Oborn CJ, Kittrell FS and Ullrich RL (1986) Properties of mouse mammary epithelial cell lines characterized by in vivo transplantation and in vitro immunocytochemical methods. J. Natl. Cancer Inst. 76: 1143-1151

26. KaeckM, Lu J, Strange R, Ip C, GantherHE and Thompson HJ (1997) Differential induction of growth arrest inducible genes by selenium compounds. Biochem. Pharm. 53: 921-926

27. Michalovitz D, Halevy $O$ and Oren M (1990) Conditional inhibition of transformation and of cell proliferation by a temperature-sensitive mutant of p53. Cell 62: $671-680$

28. Levine AJ (1997) p53, the cellular gatekeeper for growth and division. Cell 88 : $323-331$

29. Wood RD, Robins P and Lindahl T (1988) Complementation of the Xeroderma Pigmentosum DNA repair defect in cell-free extracts. Cell 53: 97-106

30. Zlatanova J, Yaneva J and Leuba SH (1998) Proteins that specifically recognize cisplatin-damaged DNA: a clue to anticancer activity of cisplatin. FASEB J. 12: $791-799$

31. Thornberry NA and Lazebnik Y (1998) Caspases: enemies within. Science 281: $1312-1316$
32. Cryns V and Yuan J (1998) Proteases to die for. Genes Dev. 12: 1551-1570

33. Ding H-F, McGill G, Rowan S, Schmaltz C, Shimamura A and Fisher DE (1998) Oncogene-dependent regulation of caspase activation by p53 protein in a cellfree system. J. Biol. Chem. 273: 28378-28383

34. Kagawa S, Fujiwara T, Hizuta A, Yasuda T, Zhang WW, Roth JA and Tanaka N (1997) p53 expression overcomes p21/WAF1/CIP1-mediated G1 arrest and induces apoptosis in human cancer cells. Oncogene 15: 1903-1909

35. Geske FJ, Lieberman R, Strange R and Gerschenson LE (1995) Evidence for DNA repair in cycloheximide-induced apoptosis using human and mouse cell lines. FASEB J. 9: A419

36. Ford JM and Hanawalt PC (1995) Li-Fraumeni syndrome fibroblasts homozygous for p53 mutations are deficient in global DNA repair but exhibit normal transcription-coupled repair and enhanced UV resistance. Proc. Natl. Acad. Sci. USA 92: 8876-8880

37. Ford JM and Hanawalt PC (1997) Expression of wild-type p53 is required for efficient global genomic nucleotide excision repair in UV-irradiated human fibroblasts. J. Biol. Chem. 272: 28073-28080

38. Kumar S and Colussi PA (1999) Prodomains-adaptors-oligomerization: the pursuit of caspase activation in apoptosis. Trends Biochem. Sci. 24: 1-4

39. Aravind L, Dixit VM and Koonin EV (1999) The domains of death: evolution of the apoptosis machinery. Trends Biochem. Sci. 24: 47-53

40. Kroemer G, Zamzami N and Susin SA (1997) Mitochondrial control of apoptosis. Immunol. Today 18: $44-51$

41. Smith ML and Fornace Jr AJ (1997) p53-mediated protective responses to UV irradiation. Proc. Natl. Acad. Sci. USA 94: 12255-12257

42. McKay BC, Francis MA and Rainbow AJ (1997) Wildtype p53is required for heat shock and ultraviolet light enhancd repair of a UV-damaged reporter gene. Carcinogenesis 18: 245-249

43. Smith ML, Chen I-T, Zhan Q, O'Connor PM and Fornance Jr AJ (1995) Involvement of the p53 tumor suppressor in repair of u.v.-type DNA damage. Oncogene 10: 1053-1059

44. Sancar A (1995) DNA repair in humans. Ann. Rev. Gen. 29: 69-105

45. Green D and Kroemer G (1998) The central executioners of apoptosis: caspases or mitochondria? Trends Cell Biol. 8: 267-271

46. Janicke RU, Sprengart ML, Wati MR and Porter AG (1998) Caspase-3 is required for DNA fragmentation and morphological changes associated with apoptosis. J. Biol. Chem. 273: 9357-9360

47. Sun X-M, MacFarlane M, Zhuang J, Wolf BB, Green DR and Cohen GM (1999) Distinct caspase cascades are initiated in receptor-mediated and chemicalinduced apoptosis. J. Biol. Chem. 274, 5053-5060

48. Casciola-Rosen L, Nicholson DW, Chong T, Rowan KR, Thornberry NA, Miller DK and Rosen A (1996) Apopain/CPP32 cleaves proteins that are essential for cellular repair: a fundamental principle of apoptotic death. J. Exp. Med. 183 $1957-1964$

49. Jackson SP and Jeggo PA (1995) DNA double-strand break repair and V(D)J recombination: involvement of DNA-PK. Trends Biochem. Sci. 20: 412-415

50. Jeggo PA, Taccioli GE and Jackson SP (1995) Menage a trois: double strand break repair, V(D)J recombination and DNA-PK. BioEssays 17: 949-957

51. Song Q, Lees-Miller SP, Kumar S, Zhang N, Chan DW, Smith GCM, Jackson SP, Alnemri ES, Litwack G, Khanna KK and Lavin MF (1996) DNA-dependent protein kinase catalytic subunit: a target for an ICE-like protease in apoptosis. EMBO J. 15: $3238-3246$

52. Stroh C and Schulze-Osthoff K (1998) Death by a thousand cuts: an ever increasing list of caspase substrates. Cell Death Differ. 5: 997-1000

53. Friedberg EC, Walker GC and Siede W (1995) Mutagenesis in prokaryotes. In DNA repair and mutagenesis. (Washington, D.C.: ASM Press) pp. 465-522

54. Leveillard T, Andera L, Bissonnette N, Schaeffer L, Bracco L, Egly J-M and Wasylyk B (1996) Functional interactions between p53 and the TFIIH complex are affected by tumour-associated mutations. EMBO J. 15: 1615-1624

55. Harvey KJ, Blomquist JF and Ucker DS (1998) Commitment and effector phases of the physiological cell death pathway elucidated with respect to bcl-2, caspase, and cyclin-dependent kinase activities. Mol. Cell. Biol. 18: 2912-2922

56. Fadok VA, Bratton DL, Frasch SC, Warner ML and Henson PM (1998) The role of phosphatidylserine in recognition of apoptotic cells by phagocytes. Cell Death Differ. 5: $551-562$

57. Steller H (1995) Mechanisms and genes of cellular suicide. Science 267: 14451449 

FJ Geske et al

Cell Death and Differentiation 